\title{
A forske med kunsten kollaborativt i en fortellerforestillingsproduksjon
}

\author{
Mette Bøe Lyngstad ${ }^{\star}$ og Kari Thorkildsen \\ HVL, Høgskulen på Vestlandet
}

\section{Sammendrag}

I denne artikkelen viser forskerne, som også er fortellere, hvordan de i utviklingen av sin egen fortellerforestilling forsket med kunsten. Artikkelforfatterne forsøker å vise en selvrefleksivitet og metodologisk bevissthet gjennom hele kunstproduksjonen. De undersøker hvordan en gjennom å forske med kunsten kollaborativt kan koble historiske fakta, fiksjonsfortelling og livsfortelling i en kunstproduksjon. Forskningsartikkelen tar for seg kunstproduksjonens ulike faser som brainstormfase, innsamlingsfase, fortellertekniske fase og utforskingsfase i scenerommet.

Nøkkelord: Kunstfaglig forskning; flyktning; reise; dramakonvensjoner; narrativer; kollaborativt; fortellerforestilling; kunstfaglig produksjon

\begin{abstract}
In this article, the researchers, who also are storytellers, writes about their art based research in creating a storyteller performance. They put focus on their self-reflexivity and methodological awareness in the art production. Through their collaboratively work they tried to link historical facts, fiction narratives and life stories in the art production. The article deals with various phases of art production such as brainstorm phase, collection phase, narrative phase and exploration phase in the stage room.
\end{abstract}

Keywords: Art based research; refugees; travel; drama conventions; narratives; collaboration; storytelling performance

Received: August, 2017; Accepted: February, 2018; Published: March, 2018

Kunstfaglig forskning har de siste 15-20 åra hatt en stadig økning (Gjærum og Rasmussen, 2012). Et nytt kunnskapsparadigme har trådt frem, der kunstnerisk utforskning verdsettes som forskning (Rasmussen, 2012). Marit Ulvund (2012) skriver om det å forske med kunsten i sin artikkel «Ekkoteater - praksisledet forskning innenfor et performativt paradigme», og Lise Hovik (2012) er opptatt av det i sin artikkel

^Korrespondanse: Mette Bøe Lyngstad, Fakultet for lærerutdanning, kultur og idrett, institutt for kunstfag, HVL 5020 Bergen. Epost: Mette.Boe.Lyngstad@hvl.no

(C) 2018 M. B. Lyngstad og K. Thorkildsen. This is an Open Access article distributed under the terms of the Creative Commons Attribution 4.0 International License (http://creativecommons.org/licenses/by/4.0/), allowing third parties to copy and redistribute the material in any medium or format and to remix, transform, and build upon the material for any purpose, even commercially, provided the original work is properly cited and states its license.

Citation: M. B. Lyngstad og K. Thorkildsen. "A forske med kunsten kollaborativt i en fortellerforestillingsproduksjon". fournal for Research in Arts and Sports Education, Special Issue: "Å forske med kunsten»Vol. 2, 2018, pp. 53-71. 


\section{B. Lyngstad og K. Thorkildsen}

«Rød Sko Savnet - en kunstnerisk forskningsreise fra hendelse til dokument». I deres forskning presenteres, diskuteres og foretas det ulike metodologiske tilnærminger og valg, og de er opptatt av å utforske den personlige fortellingen gjennom teater. I praksisbasert forskningsprosjekt vil det ifølge Ulvund (2012, s. 59) være nettopp det å skape og utøve praksisen som er selve forskningen: «undersøkelsen blir en del av den skapende prosessen, med et artistisk produkt som resultat». I denne artikkelen vil vi presentere vår kunstfaglige forskning fra en fortellerforestillingsproduksjon. Forestillingen var en del av det offisielle programmet til Hansajubileet i Bergen. Ett av målene for forestillingen var å trekke paralleller mellom eldre og nyere tid, og «Reisen mot det ukjente» ble valgt som forestillingens arbeidstittel. Vi skapte to unge gutter på 15 år, Hans, som reiste fra Lübeck i 1511 og Hassan, som reiste fra Afghanistan i 2011. Vi var opptatt av å vektlegge en kunstfaglig forskningsprosess, og undersøke hvordan vi kunne skape en fortellerforestilling fra to tidsepoker med utgangspunkt $\mathrm{i}$ vårt forskningsmateriale som er historisk materiale, litterære verk, livsfortellinger og fiksjonsfortellinger. I dette tilfellet er kunstproduksjonen selve forskningsprosjektet, og fortellerforestillingen er forskningsresultatet. Innenfor kunstfaglig forskning er det avgjørende både med selvrefleksivitet og metodologisk bevissthet både underveis og i ettertid (Rasmussen, 2012). Refleksjon i etterkant av vår kunstproduksjon er av betydning både for oss og for fremtidig publikum, da det kan gi forestillingen ny form. Våren 2018 inngår forestillingen i Den kulturelle skolesekken sitt program i Bergen kommune.

\section{Forfatterstemmene og artikkelens problemstilling}

Vi, artikkelforfattere, er i vårt daglige virke både forskere, fortellere og undervisere. På tross av mange felles kompetanseområder har vi ulik forskningserfaring og forskningsinteresse, noe som har bidratt positivt i dette forskningsprosjektet. Lyngstad har i lengre tid jobbet med innvandrere og deres personlige fortellinger ${ }^{1}$. Dette er noe vi kan dra nytte av i arbeidet med å skape troverdige fiktive personer fra historisk materiale. Thorkildsens forskningserfaring på performative uttrykk $\mathrm{i}$ teaterprosesser og teaterproduksjoner har åpnet opp for nye skapende prosesser i vår forestillingsproduksjon.

I vårt prosessuelle arbeid frem mot forestillingen var vi både forskere, fortellere og regissører. Mange forskningsmetodiske grep knyttet til kunstproduksjonen ble tatt underveis, flere av disse vil vi presentere og diskutere gjennom artikkelen. Vi hadde en metodologisk tilnærming til arbeidet. «Forskning på - og i - praksis anerkjenner praksis som prosess, som del av en større kontekst, og med behov for klare metodologiske grep for å kunne få betydning utover den enkelte praktikers horisont» (Ulvund, 2012, s. 56).

\footnotetext{
${ }^{1}$ I Lyngstad sin tidligere forskning har hun forsket på fortellerverksted der deltakerne har arbeidet med narrativer, men selve problemstillingene har vært hvorfor en skal ta i bruk fortelling i innvandrergrupper (Lyngstad, 2016) og på hvilken måte fasilitator kan fremme eller hemme demokratiske prosesser (Lyngstad, 2017) i fortellerverksted med innvandrere.
} 
I denne artikkelen vil vi sette fokus på forskningsprosjektets metodologi, og problemstillingen er: På hvilken måte kan vi gjennom å forske med kunsten kollaborativt, koble historisk materiale, fiksjon og livsfortelling $i$ en kunstproduksjon?

\section{Kollaborativ og narrativ forskning}

Kollaborativt arbeid kjennetegnes av et lærende fellesskap, der deltakerne er avhengige av hverandre og jobber tett sammen. Ifølge Jørgen Bang og Christian Dalsgaard (2005) forutsetter denne arbeidsformen en god kommunikasjon og en åpenhet ettersom prosjektet konstant utvikles, forhandles og diskuteres. Vår vekt på å gjøre prosjektet dynamisk og bevegelig i nye retninger, er i tråd med Bang og Dalsgaards tenkning. Den lange erfaringen vi har med å veilede hverandre i fortellerprosesser og skriveprosesser har hatt innvirkning både på forskningsprosessen og på forskningsresultatet. Fordi vi kjenner hverandres styrker og svakheter godt, våger vi å utfordre hverandre ytterligere og være mer direkte i tilbakemeldingene. Michael Conelly og Jean Clandinin (1990, s. 4) understreker at kollaborativ forskning krever en spesiell kontakt, der en deler erfaringer "[...] colaborative research which requires a close relationship akin to friendship». Vi er både forskerkollega, fortellerduo og venner. Dette kan på den en siden tilsi at vi kjenner hverandres kvaliteter godt og vet å fremme disse hos hverandre, mens det på den andre siden kan skape uklare forventninger til hverandres bidrag i forskningsprosjektet og være med på å låse oss i et fastgrodd mønster. Det var derfor viktig for oss at vi introduserte våre ulike perspektiver i dette kollaborative arbeidet og tilførte forskningsprosjektet ny substans.

Vår felles forskningsinteresse er innenfor narrativ tradisjon. I arbeidet med å utvikle teksten om Hans foretar vi på mange måter en klassisk narrativ historisk analyse. I arbeidet med flyktningens fortelling gjorde vi en analyse basert på andre forskningsmetoder. I fortellingen om Hans ble narrative metoder knyttet til å studere og analysere material som skiønnlitteratur, foto, historie, osv. I arbeidet med historien om Hassan utvikles derimot narrativene gjennom intervju, analyse av forestilling, feltarbeid og observasjon. Det har vært interessant å la funnene fra våre ulike tilnærmingsmetoder møtes i en og samme fortellerforestilling.

Ifølge Conelly og Clandinin (1990) vil en gjennom å studere narrativer finne ut noe om hvordan mennesker opplever verden. Mennesker speiler seg i hverandres fortellinger og påvirker hverandres fortellinger (Conelly og Clandinin, 2000; Horsdal, 2017; Lyngstad, 2016). Forskeren er med og påvirker fortellingen han forsker på, og nye fortellinger skapes. Clandinin mfl. (2015) fremhever viktigheten av å forske sammen med andre i narrativ forskning, for å unngå å bli fanget av de store fortellingene som dominerer ens forskningslandskap. I vår kunstproduksjon skapes og konstrueres to narrativer ut fra ulikt materiale, men de to fortellingene har flere fellespunkter. Begge fortellingene presenterer ungdommer som forlater sine hjem for å oppleve verden og skaffe seg en bedre fremtid. I fortellerforestillingen løftes ulike dilemmaer frem, som det å være alene og kjenne en ambivalens mellom nysgjerrighet 


\section{B. Lyngstad og K. Thorkildsen}

og frykt. I begge fortellingene møter vi ulike figurer som innvirker på protagonistens reise. Som forskere i dette prosjektet veksler vi mellom å konstruere og rekonstruere historiske fakta og personlige fortellinger knyttet til våre to figurer Hans og Hassan. I denne forskningen vil vi i tråd med Conelly og Clandinin (1990) både konstruere og rekonstruere personlige historier og sosiale historier, og vi er både fortellere og karakterer i hverandres historier.

\section{Fortellerforestillingsproduksjonen og dens forskningsfaser}

I utviklingen av vår fortellerforestilling vektla vi en menings- og kunnskapsproduksjon. Vi ønsket å utforske temaet reise fra to ulike tidsepoker, og utforske temaet gjennom fortelling, improvisasjon og spill.Vi inntok derfor ulike fiktive roller, foretok perspektivskifte og utviklet nye perspektiv på temaet.

I denne artikkelen har vi delt produksjonsperioden inn i fire ulike faser:

Fase 1. Brainstormfase

Fase 2. Innsamlingsfase

Fase 3. Fortellerteknisk fase

Fase 4. Utforskingsfase i scenerommet

Hvordan forsket vi med kunsten kollaborativt i de ulike fasene, og i hvilken grad viste vi en refleksivitet i forhold til valg av både innhold og form i de ulike fasene? Ifølge Bjørn Rasmussen (2012, s. 24) vil kunstneres og praktikeres menings- og kunnskapsproduksjon kjennetegnes av «deltakelse og medskapning, kognitiv-affektiv inngripen og forming av materialet». Vi vil se nærmere på om dette er med på å prege vår kollaborative kunstproduksjon. I tillegg vil vi komme nærmere inn på andre aspekter som vi ser har vært viktige i vår produksjon av narrativer, som valg knyttet til materiale, dokumentasjon, kontekst, osv. Selv om vi hadde klare mål om en kollaborativ forskningsprosess der begge skulle være både deltakende og medskapende i hele kunnskapsproduksjonen, kan en stille spørsmål om dette var like nødvendig i alle fasene. Vi vil spesielt undersøke hvordan vi formet materialet kognitivt-affektivt i tilknytning til utforskingsfasen i rommet. Vi var i forskningsprosessen både kunstner- og forskerteam.

\section{Fase 1: Brainstormfase}

En vel anvendt arbeidsform i startfasen av et prosjekt både innen utdanning og kunstprosjekt er brainstorm. Formen legger opp til en inkluderende idéskaping. I vår brainstorming bidrar begge med assosiative stikkord om prosjektets tematikk; reisen mot det ukjente - en lcerlings reise $i 1511$ og en flyktnings reise $i$ 2011. Forskningsspørsmålet ble utviklet gjennom å undersøke temaet, søke etter mulige kunnskapsveier til historiske fakta, assosiere, skape fiksjonsfortelling og utforske en livsfortelling. Ifølge praksisledet forskning er det viktig at forskningsspørsmålet er i utvikling (Rasmussen, 2012; Haseman og Mafe, 2009). I denne fasen var vi et lærende fellesskap hvor vi løste oppgavene sammen og foretok en brainstorming på temaet (jamfør kollaborativ 
metode). Vi skrev forløpende ned stikkord ut fra våre assosiasjoner, uten noen form for regler, strukturer eller system. Stikkord som: hav, storm, forlis, drukning, redsel, farvel, sorg, brennende sol, kulde og regn, gummibåt, fremmede språk, forventning, håp og nysgjerrighet. Dialogen som skjedde mellom oss i denne kollaborative prosessen ga nye assosiasjoner som stadig igjen ga nye assosiasjoner, og ut av dette ble det skapt et mangfoldig tankekart som avdekket vår kunnskap og mangel på kunnskap. Alt var åpent med hensyn til både form og innhold. Brainstorm som forskningsmetode gav oss et mangfold av ideer å gå tilbake til gjennom hele prosessen. Her er vi i tråd med kollaborativ metode, fellesskapet er i konstant utvikling og beveger seg i nye retninger (Bang og Dalsgaard, 2005).

Ut av vårt forskningsmateriale, som bestod av historiske kilder og transkribert intervju, skapte vi fortellingene om to hudløse, usikre gutter som begge skulle foreta en lengre reise mot et fremmed sted.Vi formet to gutter, en hanseat og en flyktning, som begge i våre øyne var for unge til å ta ut på egenhånd. Reisen ble for begge vanskelig og strabasiøs. Vi fant en interessant sammenheng mellom den hanseatiske guttens reise til Bergen rundt 1500 og Hassans usikre reise som flyktning 500 år senere. Denne koblingen ville vi løfte frem fordi vi ønsket å fremme flere perspektiver i anledning Hansajubileumet og i den pågående flyktningedebatten. Hvordan skulle vi få frem dette i kunstnerisk språk, og klare å brette ut et landskap med fortellingene, uten å trekke for tydelige tråder eller sammenhenger mellom dem? Vi var bevisste på at fortellinger kan være både meningsskapende og holdningsskapende (Østern og Angelo, 2016), og ville unngå å være for overtydelig og moraliserende i formidlingen.

I vårt forskningsarbeid kan brainstorming ses i sammenheng med devisingteaterets metoder. Devising blir ifølge Thorkildsen (2017, s. 97) ofte oversatt til selvskapt teater, og er en prosessuell teaterform hvor forestillingen skapes giennom eksperimentering og utprøving. Et vesentlig element i denne formen peker på startpunktmaterialet som betydningsfull i den videre prosessen.
Objekter, tekster, bilder og andre typer materiale blir viktig som startpunkt når det tekstbaserte manus er forlatt. Et slikt materiale er ment å sette i gang den kreative prosessen og gi deltakerne assosiasjoner til eget liv og ideer som kan deles med hverandre, noe som er et bærende element i et devisingprosjekt.

På lik linje med devising kan brainstorming med den frie, åpne og assosiative utforskningen, tolkes som et annerledes manus eller startpunkt. Vi åpnet et tankelandskap som fulgte oss videre i hele den kunstneriske forskningsprosessen.

\section{Fase 2: Innsamlingsfase}

I innsamlingsfasen ble ulike metoder tatt i bruk for å samle forskningsmateriale. I denne fasen arbeidet vi mest hver for oss. Hvis en tar kollaborativt samarbeid bokstavelig vil det si at vi fraviker metodens prinsipper når vi her velger å forske videre på hver vår del av arbeidet. På denne måten rasjonaliserte vi arbeidet, samtidig som vi også ga rom for dypere konsentrasjon omkring eget studie av innsamlingen. Muligens 


\section{B. Lyngstad og K. Thorkildsen}

benyttet vi her en kombinasjon av kooperativ og kollaborativ metode (Bang og Dalsgaard, 2005). Samtidig planla vi å samarbeide tettere i neste fase og dele den informasjon vi hadde tilegnet oss. Vi samlet inn vårt forskningsmateriale på ulike måter. Mens den ene av oss fordypet seg i historisk materiale om Hansatiden ${ }^{2}$, foretok den andre forskeren en analyse av fluktfortellinger fra i dag. Rasmussen skriver i sin artikkel om viktige aspekter ved kunnskapsproduksjon i praksisledet forskning, at kunnskapen produseres gjennom teaterprosessen. Vi tilegner oss ny kunnskap ved å søke kunnskap til forestillingen (Rasmussen, 2012).

\section{Den hanseatiske guttens historie}

I forskningsmateriale knyttet til historien om Hans inngikk historisk materiale om hansatiden og hansabyene Lübeck og Bergen. Materialet inneholdt alt fra foto, tegninger, historiske kart, historiske tekster, artikler om den politiske situasjonen på den tiden, men også små litterære fortellinger om fiktive og virkelige personer som levde i en hansaby. Studiet omfattet også arbeidet med skissetegninger og andre nedtegnelser av klesdrakter, bygninger, skuter, kirker, gater, mat, matretter, innredning av hus i senmiddelalder i Europa. Alt som kunne få betydning i løpet av prosessen. Connelly og Clandinin (2000) kaller historiene som forskeren samler «felttekster» og påpeker at det er viktig å samle informasjon også om konteksten til disse historiene. Fortellersekvensen om da hansagutten Hans tok farvel med hjembyen Lübeck har bakgrunn i historisk materiale. Kildene var studier av gamle kart som viser torgene, rådstuen og de gamle kirkenes beliggenhet, foto/bilder som viser byens eldre bygninger, historisk tekst som beskriver det flate landskapet i og rundt Lübeck by, forfatterens tegninger av gaten hvor den fiktive Hans bodde samt tørrfiskhandelens virksomhet. Dette ble Hans sine beskrivelser av byen i det han ser den forsvinne, da båten forlater byen en vårdag i 1511. Den historiske tiden formet den fiktive historien om Hans. En notatbok fulgte med forskeren i hele arbeidsprosessen. Ved å bruke notatbok fikk vi i innsamlingsperioden samlet viktige data på ett sted. Rasmussen peker på konsekvensene av å flytte seg innenfor et kunnskapsparadigme som anerkjenner kunst som forskning, er at en gjør kunstfaglige metoder og språk til forskningsmetoder (2012). «Det betyr å oppgradere notatbøker og skisser som brukes i kunstneriske prosesser til dokumentasjonsmetoder og materiale for forskning» (Rasmussen, 2012, s. 44). I løpet av innsamlingsprosessen ble det notert og analysert viktige og dramatiske hendelser mellom hanseatene og bergenserne, og vi fikk et overblikk over storhetstiden til hanseatene; handelsblokader, krig, den norske kongens privilegiebrev til hanseatene og slosskamper/drap

\footnotetext{
${ }^{2}$ Hansatiden var en periode som strakk seg over ca. 600 år, og som oppstod ca. på 1200 tallet iTyskland. Hanseatene var en laugsforening mellom handelsbyer i Tyskland på ca. 1250-tallet og spredte seg til områder i Europa hvor disse tyske byene drev handel. I handelsbyene som Hanseatene knyttet til seg bygget de opp egne gettoer hvor hanseatene bodde og drev handel. Her levde bare tyske menn, og hit var det lærlingene fra Tysland ble sendt for utdanning. Organiseringen var en måte å beskytte handelen og holde makten på hanseatenes hender.
} 
mellom hanseatene og Bergens befolkning. Notatboken med slike nedtegnelser ble et oppslagsverk, en oppslagstavle og et sted for skisser og huskelapper. Gjennom studier av senmiddelalderbyer og ikke minst bilder fra gamlebyen i Lübeck, løftes det frem sanselige affektive inntrykk: brostein, trange gater, kanaler, steinbygninger, bindingsverkshus, kirker, osv. Vi dannet oss indre bilder av guttens vandring i Lübeck; koggene som lå ved kai, inngangen til den berømte Mariakirken, osv.

Fiksjon kan ifølge Østern og Angelo (2016, s. 48) bygges over virkelige erfaringer: «Historieskriving må bruke fiksjon, ettersom det historiske forløpet kun kan tolkes og avleses gjennom de narrative koblinger som kan gjøres av de spor og de dokumenter som finnes». Det er vesentlig i historiske fortellinger at fiksjonen skaper et ytterlig lag av menneskelighet og identifisering med personer og handlinger. Historiske kilder gav detaljrike beskrivelser av sjøreisen mellom Lübeck og Bergen. Det var en farefull ferd som kunne ta mer enn 50 dager hvis været var dårlig. Underveis kunne det skje dramatiske hendelser som orkan, forlis eller at skipet ble angrepet av kapere/siørøvere. Nye forskningsspørsmål åpnet historien videre: hvordan angrep kaperne og hvordan forsvarte sjøfolkene skuten og lasten? Å gjenskape et kaperangrep, er selve det formede, kunstneriske arbeidet. Vi gjenskapte den dramatiske situasjonen ved å fantasere over og forme et historisk bilde bygget på historieskriving og diktning (Østern og Angelo, 2016). Gjennom skjønnlitterært materiale oppnår en kunnskap om levd liv. Både eget levd liv og litterær kompetanse er overførbart i det skapende arbeidet og brukes inn mot fortellingen og fargelegger resultatet.

Det er de menneskelige sidene som skaper nerven i fortellingen. For å hente frem indre bilder og beskrive hvordan hanseaten Hans opplevde havet i orkan og kuling, hentet vi inspirasjon og kunnskap fra Jacob Sandes (2006, s. 102) novelle "Brørne frå Rognaldsvika. Sande beskriver naturen med følgende språklige formulering: «Det braut bak om dei! Eit veldigt brot lyfte seg med bulder og brak, rauta og rauk som ein diger foss, fall av og tok seg oppatt». Slike formuleringer gav oss fordypet innsikt i havets mange variasjoner og bidro til større kunnskap og bevissthet $i$ eget kunstnerisk uttrykk. Kompetansen med å formulere narrative setninger utvikles i nærlesning av slike litterære tekster.Ved å studere Sandes noveller om menneskers kamp med havet, fikk vi en språklig innsikt i affektive stemninger hos mennesker som kjemper desperat for livet. Disse beskrivelsene fra novellen ble overført til unggutten Hans sitt møte med stormen på havet. Den narrative kompetansen skapte bevissthet på ordvalg, stemmebruk, kroppsspråk og åpnet opp for fortellings poetiske språk. Personer og hendelser ble knyttet til hverandre bygget på historiske fakta og litterære og fiktive situasjoner. «Den narrative kompetansen bidrar til en forklaring av et historisk forløp gjennom iscenesettelsen av en intrige i en viss sjanger» (Østern og Angelo 2016, s. 49). Vi anvendte vår kunnskap om reisen mellom Lübeck og Bergen; storm og orkan, forlis og angrep fra sjørøvere for å gi en retning til fortellingen. En annen faktor her var å skape sammenheng slik at den historiske siden av materialet fikk en troverdig sammenheng med fiksjonen. I fortellingen om Hans blir fakta om Mariakirkens 


\section{B. Lyngstad og K. Thorkildsen}

bratte tak brukt i fortellingen om farens dødsulykke. Denne dramatiske hendelsen var en utløsende faktor for morens (enkens) avgjørelse om å sende sønnen i arbeid hos hanseatene i Bergen.

\section{En flyktnings historie}

I forskningsmateriale knyttet til flyktningens historie inngår videoopptak av en fortellerforestilling der han forteller historien om sin flukt som enslig mindreårig fra Iran til Norge i 2011. En strabasiøs tur, som vitner om et sterk livsmot. Det er viktig for andre mennesker å få kjennskap til slike fortellinger for bedre å kunne forstå både seg selv og andre.

Flyktningens verbale og nonverbale fortelleruttrykk ble transkribert og analysert. De stedene det nonverbale språket var spesielt i iøynefallende ble det beskrevet i detalj. Med en forestilling som forskningsresultat, var vi opptatt av å hente frem flere bilder og beskrivelser fra forskningsmaterialet vårt som kunne forbedre resultatet. Dess klarere forståelse vi har av konteksten, dess bedre blir formidlingen. Lyngstad foretok et dybdeintervju av flyktningen, og transkriberte og analyserte det. Funnene var med på å legge grunnlaget for det kunstneriske fortelleruttrykket til Lyngstad i forskningsprosjektet.

Den erfaringen forskeren fikk gjennom å arbeide med flyktningen og andre innvandrere, veilede dem og instruere dem frem mot deres forestilling, ga henne en mer inngående kjennskap til temaet. Dette var med på å skjerpe hennes forskningsblikk i dybdeintervjuet, analysen og utforskingen av materiale frem mot forskerens fortellerforestilling. Det gjorde henne mer kapabel til å møte flyktningens historie og kunne etterspørre valgene for fortellingen han har skapt. Lyngstad plasserer seg i en narrativ forskningstradisjon og er spesielt opptatt av å forske på livsfortellinger ${ }^{3}$. Heidi Haraldsen og Siri Ingul (2016, s. 11) hevder at livsfortellingen hverken er autentisk, medfødt, ekte eller sann, men derimot utvalgt, konstruert og skapt: «Den kulturen og konteksten vi lever i, vil bidra til å konstituere innhold, forventninger og referanserammer for vår livsfortelling og forståelse av den». Det betyr at måten flyktningen forteller sin flukthistorie på for oss nordmenn, vil være helt annerledes enn om han forteller den til sine likemenn. Livsfortellingene i sin helhet vil oftest omhandle en tidsperiode fra fortid til nåtid, men gjerne også med blikk mot fremtid. Han fortalte en liten del fra sin livsfortelling, og i det materialet er det spesielt interessant å se på vendepunktet, høre hva han sier og forstå hvorfor han sier det han sier.

Narrativ teori og metode er ofte knyttet til en konstruktivistisk vitenskapstradisjon. Gjennom å fortelle forsøker man å gjøre seg selv og verden begripelig. Det er altså ikke en direkte gjengivelse av virkeligheten per se, men en språklig

\footnotetext{
${ }^{3}$ Lyngstad har tidligere forsket på fortellerverksted der deltakerne har arbeidet med narrativer. Forskningsspørsmålene har vært hvorfor en skal ta i bruk fortelling i innvandrergrupper (Lyngstad, 2016) og på hvilken måte fasilitator kan fremme eller hemme demokratiske prosesser (Lyngstad, 2017) i fortellerverksted med innvandrere.
} 
konstruksjon som forsøker å gjengi noe fra virkeligheten. Derfor er det ifølge Marianne Horsdal (2017, s. 103-104) ikke et vindu til virkeligheten i ufortolket form. Livsfortellingene kan nemlig inneholde både forestillinger, drømmer og poesi. Ifølge Horsdal er fortelleren og hovedpersonen i livsfortellingen en og samme person, og fortelleren prøver å skape mening og sammenheng ut fra der han står i dag. Det interessante i narrativ forskning blir derfor fortellerens opplevelse av handlinger og hendelser. Gjennom å forske på fortellerens livsfortellinger kan en bli klokere på hans selvoppfattelse og tilværelsestolkninger. «I kraft av fortællerens narrative konstruktion får vi et betydningsfuldt indblik i, hvem fortælleren er eller rettere, hvordan fortælleren fremstiller sig selv. Igennem fortællingene skabes fortællerens narrative identitet» (Horsdal, 2017, s. 106) Ettersom flyktningens fortellerforestilling var på fem minutter måtte den utvides om den skulle inngå som del av vår fortellerforestilling. Det var derfor nødvendig med dybdeintervju for å få en større forståelse for flyktningen sitt utgangspunkt, erfaring og opplevelse. I møte mellom intervjuobjekt og den som intervjuer utvikles fortellingen ifølge Horsdal (2017, s. 125) i et interaktivt kulturelt rom: «[...] hvor fortællinger kan utfolde sig og blive modtaget og spejlet med lydhørhed og forstålse, betyder meget for kvaliteten af interviewene og for det fælles udbytte af interviewprocessen». Her står dialogen sentralt, og begge er med og skaper fortellingen. Forskerens nære kjennskap til flyktningen kan være med på å farge det som blir sagt, både positivt og negativt. På den ene siden kan kjennskap være med å skape tillit, åpenhet, nærhet og forståelse. På den andre siden kan for tett kjennskap skape en risiko fordi intervjuobjektet kan komme til å svare det han tror forskeren er ute etter, eller forskeren lar være å spørre om det han tror informanten oppfatter som vanskelig. Lyngstad var spesielt oppmerksom på dette og bevisst på at hun som forsker er med å påvirke hva informanten forteller av sin livsfortelling og hva han holder tilbake (Conelly og Clandinin, 1990). Vi erfarte at den nære og lange kjennskapen til informanten var med å hjelpe forskerne til å forstå både informanten og konteksten bedre. Dette står i forhold til Clandinin (2015) sin fremheving av viktigheten av å leve side ved side med informanten sine fortellinger. Forskeren ble gjennom dette forskningsprosjektet medskaper av flyktningens fortelling ved å utforske den, utvide den og gi den en kunstnerisk innramming (Dahlsveen, Gjærum og Walløe, 2015).

\section{Fase 3: Fortellerteknisk fase}

I den fortellertekniske fasen gikk vi fra egenstudier og innsamling av stoff til praktisk, selvrefleksivt arbeid knyttet til kollaborativ utforsking av fortellingene. Som dramapedagoger tok vi i bruk de fire grunnelementer som analyseredskap i utforsking av fortellertekstene: Hvem er med (Figur)? Hvor foregår det (Rom)? Når foregår det (Tid)? Hva skjer (Fabel)? Dette mener vi kan ses i forhold til Connelly og Clandinin (2006) sin narrative tredimensjonalitet; det temporale (fortid, nåtid, fremtid), det personlige og sosiale (samhandling), og det kontekstuelle (situasjon og sted). 


\section{B. Lyngstad og K. Thorkildsen}

$\mathrm{Vi}$ anvendte bl.a. metoder som dagbokskriving, intervju i rolle, utviklet fiktive plantegninger og kart over fiktive landskap. Her samarbeidet vi tett og bygget på hverandres innspill i et medskapende forskningsrom (Rasmussen, 2012). Vi utforsket ved å fortelle til og demonstrere for hverandre og inntok sammen de fiktive stedene og landskapene vi skapte.

I rolle intervjuet vi hverandre vekselvis som Hans og Hassan. Intervjuet ble en forskningsmetode som ga ny kunnskap og erfaring som vi reflekterte over, noe som igjen ga nye funn som skapte utvikling. Den nye kunnskapen ble knyttet til de to fiktive figurene som skaptes: deres bakgrunn, familieforhold, fødeby, forventninger, visjoner og drømmer. Ved å tre dypere inn deres roller, fikk vi en tettere erfaring med protagonistene. Ved å male dem tydeligere i vårt indre bilde, ble det lettere å beskrive dem klarere for et publikum. Svarene ble improvisert frem, og som intervjuobjekt svarte vi umiddelbart, både affektivt og kognitivt. Rasmussen (2012, s. 30) skriver: «Virkeligheten endres idet forskeren interagerer med den. Mening er kun mulig eller interessant hvis den som skal forstå en annen, også ser at ens eget møte med den andre påvirker hvem den andre er og hva denne gjør». Gjennom dagbokskriving og intervju kom vi tettere på flere sider av Hans og Hassans personligheter, noe som påvirket og utviklet vår kunnskap som forskende praktikere. I ettertid ser vi at vi i denne delen kunne ha utforsket hverandres figurer og intervjuet fiktive venner, familie, naboer og tilfeldige forbipasserende. Rasmussen (2012, s. 33) viser til flere ulike kunnskapsformer vi ser som aktuelle i denne fasen: «Erfaringskunnen (experiential knowing) betyr et direkte møte med et fenomen hvor man erfarer nærvær til det/den andre gjennom kropp, følelser og forestillinger». Forskerne og figurene interagerer, når figurenes svar har bakgrunn i forskernes kunnskap i innsamlingsfasen. Forskerens møte med figuren påvirket den andre og forskeren kjenner nærværet av Hans og av Hassan. Det samme blikket kan man ifølge Rasmussen (2012, s. 45) ha på kunsten som språklige medium: «I praksisledet forskning er kunstprosessen i seg selv en språklig meningsskapende forskningsprosess (presenterende kunnen) som formidler seg selv i sin egen «språkform»».

I kollaborativt arbeid må det være en spesiell kontakt, der en deler erfaringer, er innbyrdes avhengig av hverandre og arbeider mot et felles mål (Bang og Dalsgaard, 2005). I vårt teamarbeid, oppsto den spesielle kontakten som bidro til at vi delte kunnskap med hverandre $\mathrm{i}$ en medskapende prosess frem mot forestilling. $\AA$ A dele med hverandre krever at partene er villige til å lytte og bidra aktivt i samarbeidet. En slik form for samarbeid krever mer tid sammen, og kan derfor stå i motsetning til kooperativt samarbeid hvor arbeidet blir fordelt mer effektivt mellom partene.

Østern og Angelo viser til at kvalitet i narrativ forskning bygger på gyldighetskrav om at forskeren skaper fortellingen, og dette er en måte å fremstille fortellingen på, mens det finnes flere andre måter å fremstille en slik fortelling. Det er også forskerens ansvar å redegjøre for hvorfor fortellingen fortelles slik den gjør. Først og fremst er det den etiske siden av forskerens arbeid som har stor betydning for kvaliteten $\mathrm{i}$ 
narrativ forskning (Østern og Angelo, 2016). Vi ønsket å dekonstruere det historiske materiale fra hansatiden og fremstille hanseatenes historier i lys av fortellinger fra vår tid. Derfor skapte vi en fortellerforestilling som besto av to unge gutters skjebner. Fortellingene er ladet med våre meninger, synspunkter, følelser og kunnskap. De er formet ut fra vår fortellerkompetanse, våre kunstfaglige erfaringer. Vi koblet sekvenser fra Hans og Hassans historie sammen, for å se deres historier opp mot hverandre.Vi så noen sentrale felles trekk ved deres reise på havet. I begge tilfeller ble havet avgjørende og farlig. Hassans redsel ble forbundet med smuglernes utnyttelse av flyktninger som ble sendt i overfylte gummibåter til det uvisse og Hans sin frykt for angrep fra kaprerne. Det kollaborative løftet frem viktige sammenhenger i fortellersekvensene og skapte tilknytningspunkter mellom de to tidene. Vi dekonstruerte fortellingene og satte dem sammen på nye måter. Med henvisning til Currie fremhever Østern og Angelo (2016, s. 42) at "den tradisjonelle narratologiens forsøk på å skape en koherent og stabil fortelling er dekonstruert». I følge Rasmussen (2012) er forming av materialet en vesentlig side i kunstnerens og praktikerens mening og kunnskapsproduksjon. Gjennom praktiske og metodiske øvelser og eksperimentering med stemmen, språket og ordene endres fortellingene. Hvordan vi utforsket selve fortellingene fysisk på gulvet ser vi mer på i neste fase.

\section{Fase 4: Utforskning av fortellingene i scenerommet}

I denne fasen utforsket vi tekstene ytterligere gjennom bruk av både kropp, stemme og rom for å forme fortelleruttrykket. Tekstene ble videre beskåret, omskapt og utformet.

I denne kunnskapsprosessen skapte både kolliderende og sammenfallende intensjoner reflekterende utvikling for kunstner-forskerne (Rasmussen, 2012). Refleksjonen skjer gjennom fiksjon i kunstproduksjonen. Da vi startet utforskningen med fortellingene i rommet, var det med utgangspunkt i nedskrevne tekster som ikke var ferdige. Vi utforsket ved å fortelle fortellingen for hverandre, men med støttearkene like ved. Selv om en forteller ofte opplever umiddelbart at deler av teksten ikke fungerer og må bearbeides, er det likevel en stor fordel å ha en lytter utenfra. Det kan på den ene siden være sårbart å ha noen så nært på utformingen av teksten så tidlig i utviklingsfasen, men på den andre siden kan det styrke uttrykket om en gir hverandre positiv feedback på det som fungerer.

\section{Kryssklipping av fortellingene - en eksperimentell kunstpraksis}

I løpet av fortellerprosjekt om Hassan og Hans erfarte vi i en periode at den gode prosessen stoppet opp, som om vi ikke fant nye retninger i materialet. Et forskningsspørsmål dukket opp: fulgte vi bare problemstillingen og forskningsprosessen vi selv hadde staket ut uten å se etter andre spor? Både i praksisledet forskning og i kunstnerisk utforskning oppstår det utfordringer knyttet til den kunstneriske erkjennelses- og formingsprosessen (Rasmussen, 2012). Som svar våget vi å overskride hva vi anså som fornuftig og valgte å skape brudd med det 


\section{B. Lyngstad og K. Thorkildsen}

etablerte i tekstene. For å skape brudd anvendte vi teknikker fra devisingtradisjonen. Disse benyttes ofte for å utforske tilfeldigheter som oppstår underveis i prosessen. "Change techniques offered new meaning connections to occur in that they cultivated randomness and 'accidents' instead of traditional reason structures that no longer corresponded to the larger development in society" (Haagensen, 2014, s. 70). Slike teknikker snur gjerne opp ned på vante forestillinger og lar aktørene trekkes mot et mer utforskende landskap som ikke er definert. Vi utforsket alle handlingene vi hadde skapt gjennom å klippe teksten opp i mindre deler og tilføre nye uttrykk. Vi satte så sammen delene på nytt og på nytt, og nye historier vokste frem. Sekvenser fra Hassans historie ble for eksempel en del av hansaguttens historie idet Hassan forlater hjemmet, går over fjellet og møter Hans på havet. En slik prosess er avhengig av kollaborativt arbeid, at vi «eier» stoffet sammen og er åpne for å søke og utforske retninger som vi ikke vet resultatet av og som fremmer nye fortellergrep.

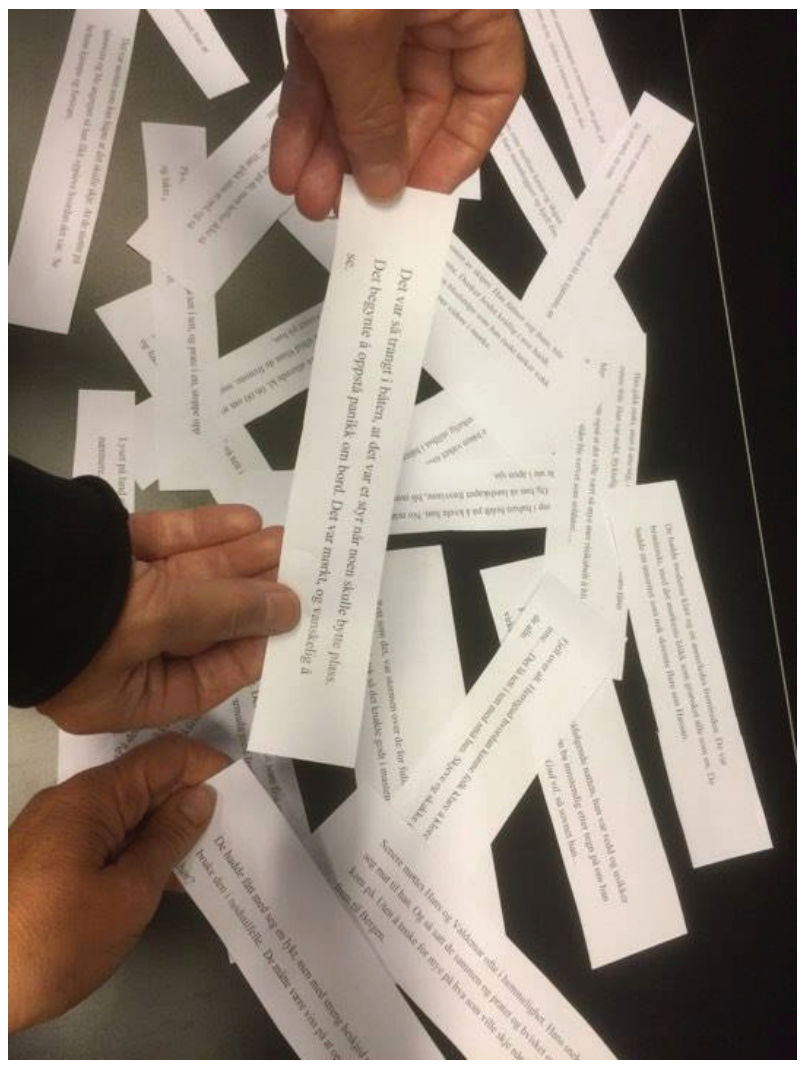

Bilde 1: Vi fortalte nye fortellinger for hverandre, med utgangspunkt i løsrevete tekstbiter. Vi utforsket teksten igjen og igjen. 
I følge Rasmussen (2012) innebærer kunstnerisk utforskning at en gjennom (ut)forskningsaktiviteten aktivt søker å gi form til en ide eller endre en del av en virkelighet. I vårt arbeid var vi klare på at vi skulle gi vårt forskningsmateriale en kunstnerisk fortellerform. Gjennom kryssklipping anvendte vi kunstnerisk forskning og utforsket et problem, erfarte og analyserte. Hvilke muligheter oppstår ved å eksperimentere slik med tekstene? Det gir en form for frihet når en bryter med det sedvanlige. Det gir løfte om at alt er mulig, alt kan skje. Det åpner opp for fantasi og gir energi til å skape. Og muligens kan Hassan sin tur over fjellet komme i en drøm som ble fortalt om bord på en hansakogge 500 år tidligere. En slik tekstklipping kan oppleves som kaotisk men også befriende og humoristisk. Slik oppdaget vi andre fortellerstrukturer som kunne anvendes da vi var tilbake til hver våre fortellingsdeler. Hovik (2012, s. 83) skriver om sin kunstneriske praksis: «I denne prosessen har ikke målet vært å lykkes, men derimot å prøve ut, oppdage og åpne for nye erfaringer». Vi erfarte at den skapende prosessen krevde en forskende praktiker som våget å være til stede i materialet og oppdage det på nytt. Fokuset vårt var drevet av et ønske om å oppleve og erfare nye sider av materialet.

Som en del av utforskingsfasen jobbet vi med å plassere fortellingene i rommet. Hvor var for eksempel huset til Hassan, hvor kom lyset inn i rommet, hvor stod moren, hvor var døren, i hvilken retning gikk han da han skulle til torget, da han flyktet osv. Ved å plassere de ulike elementene fiktivt i rommet var det enklere å være presis med blikket og de fysiske handlingene. I fortellerforestillinger, på lik linje med teaterprosesser, er tanke, opplevelse og erfaring basert på den kroppslige handlingen, hvor bevegelsen er sentral (Ulvund, 2012). Samarbeidet vårt var i utviklingsfasen eksistensielt, da vi fulgte hverandres utvikling tett og foretok en kritisk refleksjon underveis både på eget og den andres uttrykk. I tråd med Ulvund (ibid., s. 69) syntes noe av vår hovedutfordring å være «[...] å hente å hente fram og bevisstgiøre kroppslig ervervet kunnskap, samt å forstå og fortolke denne». I prosessen med å utforske flere nye roller, tok vi med oss egen ervervet kunnskap inn i fortolkningsprosessen. Disse spillsekvensene ga en annen erfaring med og forståelse av tematikken, og læringskurven vår var spesielt høy i denne fasen.

Vi var innstilt på å lytte til hverandre og være hverandres instruktør, medskaper, medforteller og forskende partner. Da arbeidet med fortellingen om Hassan stoppet opp, kom ikke fortelleren videre før medfortelleren sa direkte ifra om at en her måtte våge å løsrive handlingene mer fra flyktningens fortelling, og heller la seg inspirere av den. Det ble foretatt et bevisst valg om å distansere seg fra flyktningens fortellerform, for så å forske på egne formmessige grep. Fortellingen ble utforsket giennom sine indre bilder, jf. Rasmussens (2012) tenkning rundt erfaringskunnen. Fortelleren hadde behov for å skape flere indre bilder enn de flyktningen beskrev og valgte derfor å utforske fortellingen kroppslig sammen med medfortelleren ved å spille ut ulike scener og ta ulike rolleperspektiv. Den innebar 


\section{B. Lyngstad og K. Thorkildsen}

at utøveren i tillegg til å spille Hassan, spilte moren, andre barn på markedet og smuglerne for å utforske ulike situasjoner. I tillegg spilte vi begge ulike roller $\mathrm{i}$ hverandres fortellinger.

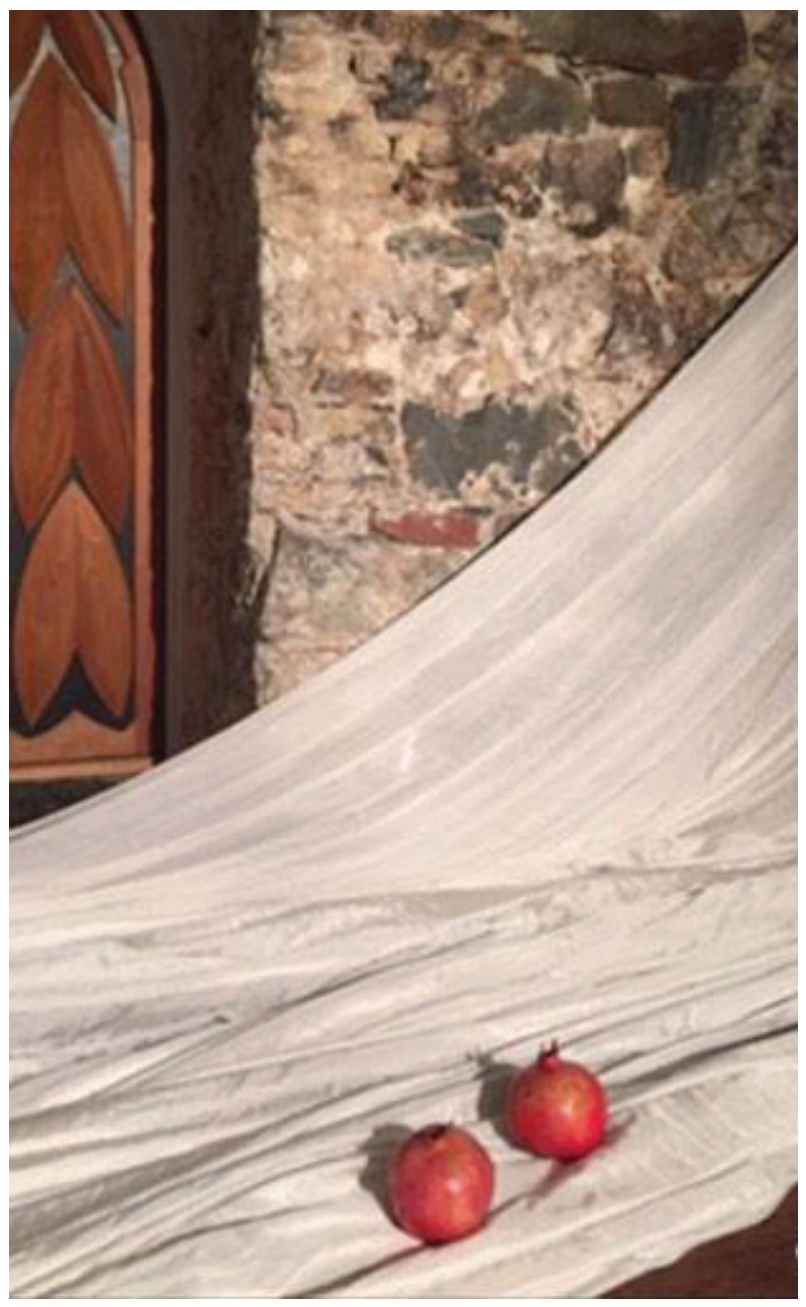

Bilde 2: Scenografiske elementer fra forestillingen.

Foto: Sturle J. Monstad.

En prosessuell forestilling er ikke ferdig før forestillingen starter (devising). Noe kan endres, noe nytt kan legges til, noe kan strykes (jf. devisingprosess). Vår forestilling bygger på improvisasjon. Like fullt er forestillingen basert på en innøvd ramme, med tydelige, presise uttrykk både med hensyn til fortellernes struktur og det fysiske uttrykket. Av den kunstneriske prosessens ulike faser som brainstormfase, innsamlingsfase, fortellerteknisk fase og utforskningsfase i scenerommet, var det den sistnevnte fasen som skapte flyt mellom stemmens språk og fortellingens visuelle virkemiddel. 


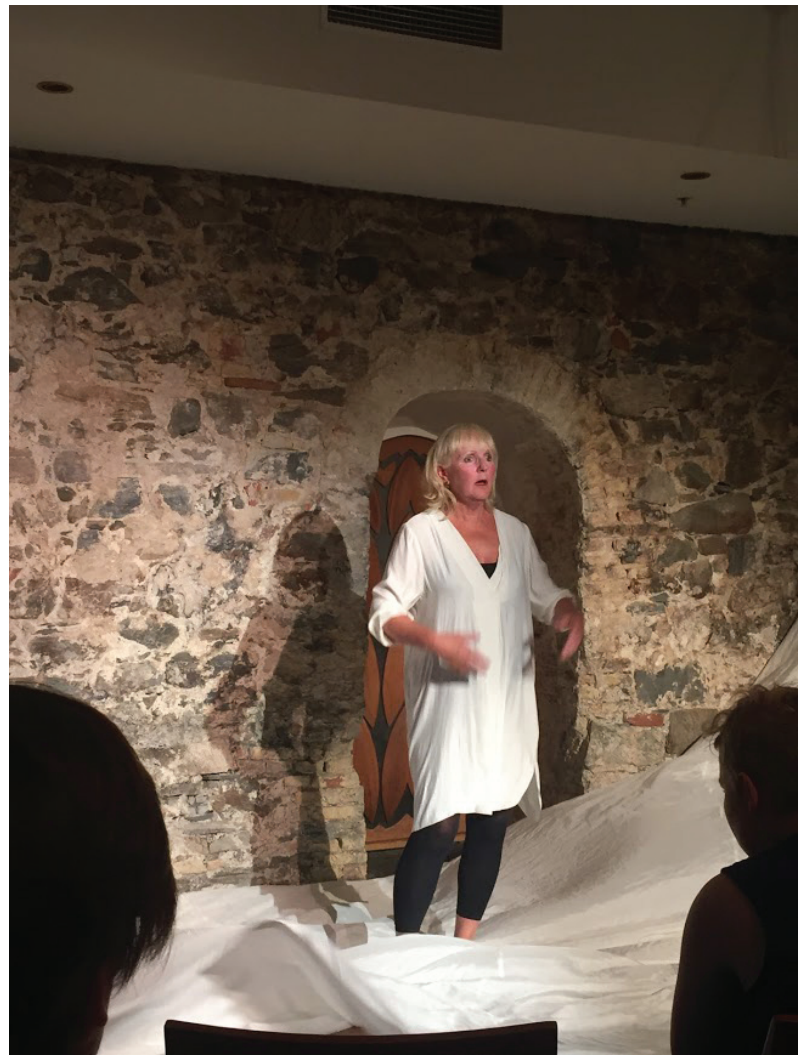

Bilde 3: Silkestoffet transformert som hav.

Foto: Sturle J. Monstad.

Underveis i prosessen undersøkte vi fortellingene gjennom å spille roller og eksperimentere med kroppens uttrykk. Noen av rollene ble ført videre og iscenesatt som symbolske uttrykk, som et sårt farvel, som sjømenn i det de klamret seg til den imaginære masten på skipet da det ble storm eller som fiskere i det de skubber båten ut fra stranden. At forestilling bygger på improvisasjon og ikke er spikret i detaljer, giør den formbar og skaper muligheter for å kunne utvikles videre. Noe kan endres, noe nytt kan legges til, noe kan strykes. Dette stiller krav om å være lydhøre overfor hverandres innspill og uttrykk. Det kollaborative gjelder derfor i aller høyeste grad også under forestillingen og refleksjonen over den i etterkant.

\section{Avslutning}

I denne artikkelen har vi fremhevet vår selvrefleksivitet og metodologiske bevissthet om det å forske med kunsten gjennom en fortellerforestillingsproduksjon. Vi forsket på vår egen prosess ved å utvikle vår fortellerforestilling, der begge to var deltakende, medskapende og aktivt med på å forme fortellermaterialet. I denne prosessen foretok vi kollaborativt en kognitiv-affektiv inngripen i forskningsmaterialet 
M. B. Lyngstad og K. Thorkildsen

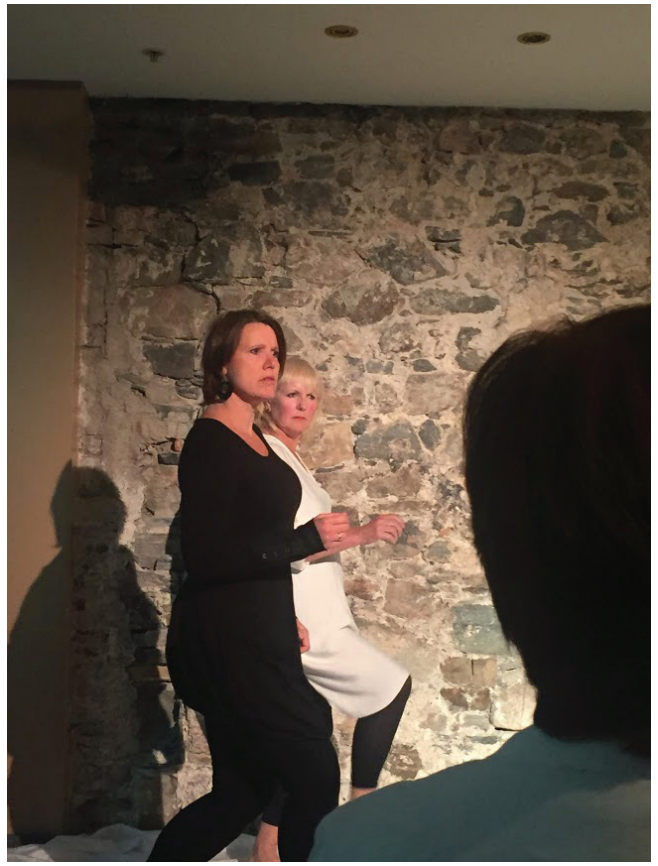

Bilde 4: Smuglerne ankommer åstedet.

Foto: Sturle J. Monstad.

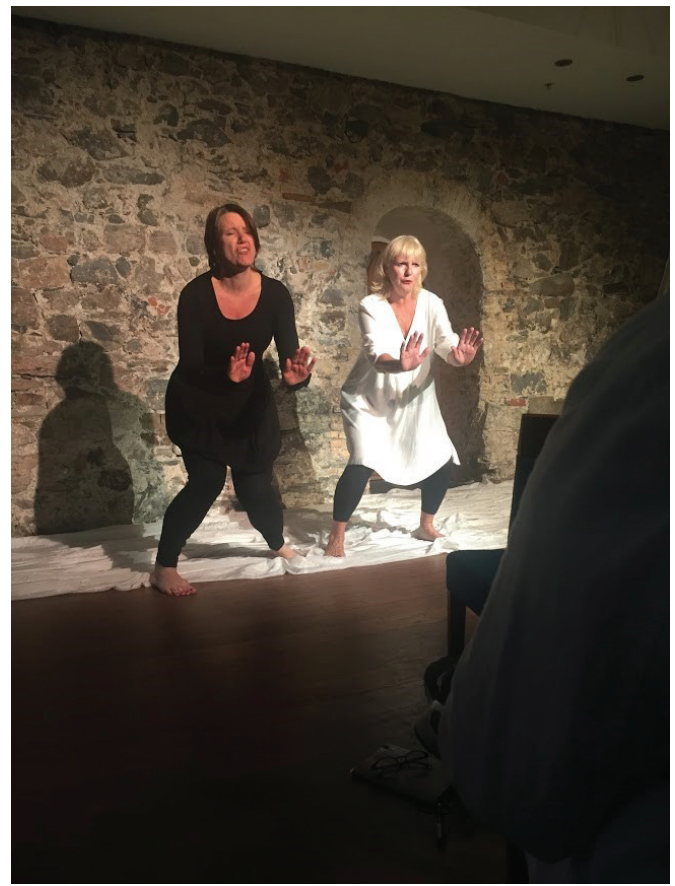

Bilde 5: Smuglerne skyver båten fra land.

Foto: Sturle J. Monstad. 
(Rasmussen, 2012).Våre forskningsspørsmål har stadig vært i utvikling og endret seg underveis i møte mellom oss forskere og våre møter med figurene i materialet. Vi har flere steder pekt på relevante kontekster (tid, rom, historisk stoff, fakta, nyheter, med mer), som har hatt betydning for utviklingen av våre to narrativer.

Praksismetodene gjennom hele prosessen har også vært våre forskningsmetoder, og våre fortellinger fikk en ny dimensjon da vi utforsket dem gjennom estetisk form. Dilemmaene ble utforsket både verbalt og nonverbalt i fiksjonen. Utforskningen skjer gjennom å agere i situasjoner, interagere med fortellingenes figurer, motta innspill giennom fysiske og kroppslige dialoger. Ved å bidra inn i hverandres fortellinger, kunstneriske famlinger og utprøvinger, gis det støttende og utfordrende innspill til hverandre.

På mange måter ble vår forteller- og teaterpraksis et forskningslaboratorium (Rasmussen, 2012). Gjennom å forske med kunsten utforsket vi ulike fortellerstiler og ble mer bevisste på hvilke fortellergrep vi foretok og hvordan de påvirket fortellingens form. To parallelle tekster vokste frem. Gjennom å utforske det nonverbale språket kollaborativt i scenerommet, tilførte vi fortellingene mer kraft ved å skape ulike scener og gi materialet en performativ tilnærming. Vi improviserte, forsterket og forminsket hendelsene samt utforsket begges fortellinger giennom teatral form. I forestillingen valgte vi å ta med flere av de scenene vi hadde improvisert frem underveis. Det ga fortellerforestillingen en mer eksperimenterende og teatral form, der flere av birollene ble bedre presentert gjennom spill enn ord. Gjennom en kollaborativ utforsking av ulike posisjoner, fortellermåter, scenografi, rekvisitter og spillestil i begge fortellingene, fikk vi revitalisert eldre historisk stoff og koblet det til en samtidsaktuell problemstilling. Også flyktningeproblematikken ble satt inn i et større historisk perspektiv.

I dette forskningsprosjektet erfarte vi at det var utviklende å arbeide kollaborativt, da den enes ideer ble fulgt opp av den andre. Vi erfarte, oppdaget og opplevde ulikt pga. vår ulike bakgrunn, erfaringer og interesser, og nettopp derfor opplevdes det kollaborative arbeidet så fruktbart. Vi har tatt del i et lærende fellesskap (Bang og Dalsgaard, 2005), preget av en åpen og direkte kommunikasjon. Det kollaborative har vært til stede i alle faser, bortsett fra innsamlingsfasen, da vi i den fasen vektla individuell fordypning. I ettertid har vi sett at dette både var en svakhet og en begrensning, ettersom vi ikke fikk samme eierforhold til den andres materiale. Ved neste anledning vil vi jobbe kollaborativt også i denne fasen.

\section{Forfatterpresentasjon:}

Mette Bøe Lyngstad er forteller og førstelektor i drama ved Institutt for kunstfag ved Høgskulen på Vestlandet (HVL). Hennes forskningsfelt er knyttet til drama i undervisningen, anvendt teater og muntlig fortelling $\mathrm{i}$ marginale grupper. I de siste årene har fokuset på interkulturelt arbeid resultert i flere fortellergrupper med innvandrere og fortellerforestillinger. Lyngstad sine siste forskningsartikler er: "Casestudie av fortellerverksted med innvandrerkvinner» i Gürgens, Rasmussen og Heggstad (2017) Drama, teater og demokrati. Antologi $2 \mathrm{i}$ kultur og samfunn, "Foreldrene forteller - en undersøkelse av fortellerprosjekt med innvandrermødre» i Solbue og Bakken (2016). Mangfold $i$ skolen, «Generalprøve på virkeligheten? Utforsking av praksisfortellinger 


\section{B. Lyngstad og K. Thorkildsen}

gjennom forumteater» i Eriksen Ødegaard og Økland (2015). Fortellinger fra Praksis og «Teater-i-undervisningen som danningsarena - en studie av studentenes TIU-prosjekt» i Heggstad, Eriksson og Rasmussen (2013). Teater som danning. mette.boe.lyngstad@hvl.no

Kari Thorkildsen er forteller og førstelektor i drama og teater ved Institutt for kunstfag, Høgskulen på Vestlandet (HVL). Hennes forskningsinteresse er anvendelse av samtidskunstens estetiske form i utdanning av barnehagelærere. Hun har vært med på å utvikle kunstfaglig førskolelærerutdanning ved HVL, campus Bergen. Thorkildsen sine siste forskningsartikler er: "Når engler tar av - en teaterproduksjon i demokratiets ånd" i Gürgens, Rasmussen og Heggstad (2017) Drama, teater og demokrati. Antologi 1 i barnehage, skole, museum og høyere utdanning. "Verden snudd på hodet! Surrealisme som didaktisk prosjekt- et bidrag tl lek og teaterkompetanse.» i Heggstad, Eriksson og Rasmussen (2013). Teater som danning og "Den ville babyreisen" i Bakke, Jenssen og Sæbø. Kunst, kultur og kreativitet (2011). Hun underviser primært i barnehagelærerutdanningen samt har undervisning i fortellerkunst på Bachelor i drama og anvendt teater. kari.thorkildsen@hvl.no

\section{Litteratur}

Bang, J. \& Dalsgaard, C. (2005). Samarbejde - kooperation eller kollaboration? København. Tidsskrift for Universiteternes Efter- og Videreuddannelse, (UNEV) 2(5), 1-12.

Dahlsveen, H., Gjærum, R. G. \& Walløe,T-A. (2015). Med hvilken rett blir din sigøynerhistorie min fortellig? Om innsamlings- og fortolkningsproblematikk i InFormation. Nordic fournal of Art and Research, 4(2), $1-15$.

Connelly, M. \& Clandinin, J. (1990). Stories of experience and narrative inquiry. Educational Researcher, 19(42), 2-14.

Clandinin, D. J., \& Connelly, F. M. (2000). Narrative inquiry: Experience and story in qualitative research. San Francisco, CA: Jossey-Bass Publishers.

Connelly, M \& Clandinin, J. (2006). Narrativ Inguiry. I J. Green, G. Camilli \& P. Elmore (red.), Handbook of complementary methods in education research (s.477-487). Mahwah: Lawrence Erlbaum.

Clandinin, J, Caine, V., Estefan, A., Huber, J. Shaun Murphy, M. \& Steeves, P. (2015). Places of Practice: Learning to Think Narratively. Narrative works: Issues, investigations E interventions, 5(1), 22-39.

Gjærum, R. G. \& Rasmussen, B. (2012). Vitenskapsteori og kunnskapssyn i anvendt drama-/teaterforskning. I R. G. Gjærum \& B. Rasmussen (red.), Forestilling, framføring, forskning. Metodologi i anvendt teaterforskning (s. 7-20). Trondheim: Akademika.

Haraldsen, H. \& Ingul, S. (2016). Narrativ identitet i et mangfoldperspektiv. I K. Bjerkestrand, S. Brahmachari, H.M. Haraldsen, S. Ingul og A.S. Songe-Møller (red.), Narrativ Identitet. Drama- og teaterpedagogisk praksis i interkulturell kontekst (s.6 -20). Vollen: Tell forlag.

Haseman, B. \& Mafe, D. (2009). Acquiring know-how: research training for practice-led researchers. I H. Smith \& R. Dean (red.), Practice-led Research, Research-led Practice in the Creative Arts (s. 211-228). Edinburgh: Edinburgh University Press.

Horsdal, M. (2017). Tilvcerelsens fortellinger. Tilegnelse og anvendelse. København: Hans Reitzels forlag.

Hovik, L. (2012). Rød Sko Savnet - en kunstnerisk forskningsreise fra hendelse til dokument. I R. G. Gjærum \& B. Rasmussen (red.), Forestilling, framføring, forskning. Metodologi $i$ anvendt teaterforskning (s. 77-101). Trondheim: Akademika.

Haagensen, C. (2014). Lived Experience and Devised Theatre Practice. A study of Australian and Norwegian Theatre Students' Devised Theatrical Practice. (Diss.). Trondheim: NTNU Norges teknisk-naturvitenskapelige universitet.

Lyngstad, M. B. (2016). Foreldrene forteller. En undersøkelse av et fortellerprosjekt med innvandrermødre. IV. Solbue \& Y. Bakken(red.), Mangfold i skole. Fra politisk vilje til flerkulturell virkelighet (s. 185-205). Bergen: Fagbokforlaget.

Lyngstad, M. B. (2017). Casestudie av fortellerverksted med innvandrerkvinner. I K.M. Heggstad, B. Rasmussen, B \& R.G. Gjærum (red.), Drama, teater og demokrati (s. 97-115). Bergen: Fagbokforlaget.

Rasmussen, B. (2012). Kunsten å forske med kunsten. Et blikk på kunnen ut fra praksis-teori-relasjonen. I R. G. Gjærum \& B. Rasmussen (red.), Forestilling, framføring, forskning. Metodologi i anvendt teaterforskning (s. 23-49). Trondheim: Akademika.

Sande, J. (2006). Brørne frå Rognaldsvika. I Noveller $i$ samling (s. 99-104). Trondheim: Gyldendal.

Thorkildsen, K. (2017). Når engler tar av - en teaterproduksjon i demokratiets ånd. I A.B. Sæbø, S.A. Eriksson \& T.H. Allern (red.) Drama, teater og demokrati (s. 95-108). Bergen: Fagbokforlaget. 


\section{A forske med kunsten kollaborativt i en fortellerforestillingsproduksjon}

Ulvund, M. (2012). Ekkoteater - praksisledet forskning innenfor et performativt paradigme. I R. G. Gjærum \& B. Rasmussen (red.), Forestilling, framføring, forskning. Metodologi $i$ anvendt teaterforskning (s. 51-75). Trondheim: Akademika.

Østern, A. \& Angelo, E. (2016). Riccoeur teori om fortellingens trefoldige mimes og narrativ tilnærming til musikkpedagogisk forskningspraksis. Nordisk musikkpedagogisk forskning, Arrbok 17, 41-63. 